28. Von Weizsäcker V. Fälle und Probleme. Anthropologische Vorlesungen in der medizinischen Klinik. In: Achilles P, Janz D, Schrenk M, et al, eds. Fälle und Probleme. Klinische Vorstellungen, Volume 9, Collected Works. Frankfurt am Main: Suhrkamp Verlag, 1988:15-279.

29. Donne J. Devotions upon Emergent Occasions. Ann Arbor: University of Michigan Press, 1960:138-9.

30. Østli K. Kampen mot kreften. Historien om Nicole [The fight against cancer. The history of Nicole]. A-Magasinet 2006;5:8-17.
31. Jaspers K. General Psychopathology. vol. 2. Baltimore/London: The Johns Hopkins University Press, 1997:751

32. Rorarius W. Viktor von Weizsäckers Pathosophie. Stuttgart/New York: Georg Thieme Verlag, 1991:130.

33. Dreher W. Das pathosophische Denken Viktor von Weizsäckers. Bern/Frankfurt/M: Herbert Lang/Peter Lang, 1974:171

34. Toombs SK. Illness and the paradigm of lived body. Theor Med 1988;9:201-26.

35. Leder D. The Absent Body. Chicago: University of Chicago Press, 1990.

\title{
Poetry and prose
}

\section{In passing}

The last time I saw my grandmother Po alive, she wore brown twill slacks, a thin apron, perfume of water lily, ginger, jasmine.

Now her face is bloated, rounder than I remember. Hair white at the roots, tips still purple from her do-it-at-home dye kit.

Tubes removed from her throat; the army of machines stands down. My grandfather bent over her body, anointing her cheek with tiger balm, repeating yesterday we were shopping, yesterday we were grocery shopping. I imagine them pushing a cart down an aisle of apples.

Grandfather's fingers trace the deep lines of Po's hands, the words come softly through his lips won't be long till I am walking with you.

I see first $P_{0}$ 's bound feet under the sheet: crippled since infancy, finally resting. Obsolete relics, long abandoned.

How many times I unwrapped layered strips of cotton to wash her toes with mild soap, soaking them in warm water and chamomile.

Tonight, in the bathtub, I will bend my toes under, imitating Po's bandages with a wet washcloth, releasing my feet back into the steaming water like freed fish.

Later I will learn how the doctors shocked Po's fragile body on the count of one, two, three, the way she rose into the air, for a moment suspended like flying,

like falling.

I am too young to know complicated tears.

Motionless at her side I do only what a grandchild

does for a grandmother before parting-

I lean down to her cooling forehead and kiss it.

\section{Lauren Kelley-Chew}

Correspondence to Lauren Kelley-Chew, 4233 Parkman Ave, Pittsburgh, Pennsylvania 15213, USA; laurenkc@stanford.edu Competing interests None.

Provenance and peer review Not commissioned; internally peer reviewed.

Published Online First 27 June 2012

Med Humanit 2012;38:49. doi:10.1136/medhum-2011-010046 